\title{
Estimation of the global amount of submarine gas hydrates formed via microbial methane formation based on numerical reaction-transport modeling and a novel parameterization of Holocene sedimentation
}

\author{
E.B. Burwicz*, L.H. Rüpke, K. Wallmann \\ Leibniz-Institut für Meereswissenschaften (IFM-GEOMAR), Kiel, Germany
}

Received 6 August 2010; accepted in revised form 17 May 2011; available online 25 May 2011

\begin{abstract}
This study provides new estimates for the global offshore methane hydrate inventory formed due to microbial $\mathrm{CH}_{4}$ production under Quaternary and Holocene boundary conditions. A multi-1D model for particular organic carbon (POC) degradation, gas hydrate formation and dissolution is presented. The novel reaction-transport model contains an open three-phase system of two solid compounds (organic carbon, gas hydrates), three dissolved species (methane, sulfates, inorganic carbon) and one gaseous phase (free methane). The model computes time-resolved concentration profiles for all compounds by accounting for chemical reactions as well as diffusive and advective transport processes. The reaction module builds upon a new kinetic model of POC degradation which considers a down-core decrease in reactivity of organic matter. Various chemical reactions such as organic carbon decay, anaerobic oxidation of methane, methanogenesis, and sulfate reduction are resolved using appropriate kinetic rate laws and constants. Gas hydrates and free gas form if the concentration of dissolved methane exceeds the pressure, temperature, and salinity-dependent solubility limits of hydrates and/or free gas, with a rate given by kinetic parameters. Global input grids have been compiled from a variety of oceanographic, geological and geophysical data sets including a new parameterization of sedimentation rates in terms of water depth.

We find prominent gas hydrate provinces offshore Central America where sediments are rich in organic carbon and in the Arctic Ocean where low bottom water temperatures stabilize methane hydrates. The world's total gas hydrate inventory is estimated at $0.82 \times 10^{13} \mathrm{~m}^{3}-2.10 \times 10^{15} \mathrm{~m}^{3} \mathrm{CH}_{4}$ (at STP conditions) or, equivalently, 4.18-995 Gt of methane carbon. The first value refers to present day conditions estimated using the relatively low Holocene sedimentation rates; the second value corresponds to a scenario of higher Quaternary sedimentation rates along continental margins.

Our results clearly show that in-situ POC degradation is at present not an efficient hydrate forming process. Significant hydrate deposits in marine settings are more likely to have formed at times of higher sedimentation during the Quaternary or as a consequence of upward fluid transport at continental margins.
\end{abstract}

(c) 2011 Elsevier Ltd. All rights reserved.

\section{INTRODUCTION}

Gas hydrates are solid ice-like crystalline compounds in which hydrocarbon molecules are trapped within cages of host water molecules. Guest molecules include also higher

\footnotetext{
* Corresponding author.

E-mail address: eburwicz@ifm-geomar.de (E.B. Burwicz).
}

hydrocarbons but methane is the most common one, which makes marine hydrates a potential energy resource and an important reservoir in the global carbon cycle.

In marine settings, gas hydrates are known to occur along passive and active continental margins where the physical conditions and organic carbon input favor their formation. In fact, hydrates are only stable at high pressure and low temperature conditions and a sharp phase 
boundary separates them from the free gas phase situated below. Hydrates are thus vulnerable to regional and global changes in sea level and temperature.

Sudden release of methane, a greenhouse gas with a global warming potential about 25 times higher than $\mathrm{CO}_{2}$, may also be a trigger of climate change. A catastrophic methane release as a result of marine hydrate dissociation is a hypothesis explaining a marked negative carbon isotopic excursion during the latest Paleocene (Kennett and Stott, 1991; Dickens et al., 1995).

Melting of marine hydrates and subsequent venting of methane into the water column may, in fact, occur at present as a result of a warming seafloor in the Arctic (Shakhova and Semiletov, 2007; Westbrook et al., 2009). Gas hydrates might also be a future energy source with the total volume of hydrocarbon gas locked within clathrate structures being potentially up to 10 times greater than the conventional gas reserves $\left(0.436 \times 10^{15} \mathrm{~m}^{3}, 2000\right)$.

Quantifying the role of marine hydrates in the Earth System requires global estimates on their distribution and abundance. This has resulted in a rapidly increasing number of publications exploring the various aspects of their formation (Milkov, 2004). On a regional scale, numerical modeling is complementing a wealth of observational studies and progressively helps to understand hydrate formation and dissolution processes in important gas hydrate provinces, i.e. Hydrate Ridge, offshore Oregon (Luff and Wallmann, 2003; Torres et al., 2004; Liu and Flemings, 2006; Garg et al., 2008). Global predictions rely on numerical modeling (Buffett and Archer, 2004; Klauda and Sandler, 2005; Archer et al., 2008) and region-by-region extrapolation (i.e. adequate for passive and active margins) of the total amount of hydrate-bearing marine sediments and locally inferred fraction of hydrates (Kvenvolden and Lorenson, 2001; Milkov, 2004). Recently published estimates on the global carbon inventory locked up in offshore hydrates vary over several orders of magnitude from 500 to 57,000 Gt C (Kvenvolden and Lorenson, 2001; Buffett and Archer, 2004; Milkov, 2004; Klauda and Sandler, 2005; Archer et al., 2008). There is clearly an urgent need to better constrain these global estimates to evaluate both the resource potential and the contribution of hydrates to past and future climate change.

A common proxy to hydrate inventory is the Gas Hydrate Stability Zone (GHSZ) which is defined as a combination of physical parameters (pressure and temperature conditions), and, to a smaller degree, pore fluids salinity. While it does illustrate the volume of sediment inside the stability zone it does not provide information on the actual hydrate saturation. The formation of hydrates is, in fact, mainly controlled by methane supply either through the direct degradation of organic matter within the GHSZ or through an upward flux of deeper biogenic and thermogenic methane. Such gas fluxes have been reported from active margins but unfortunately, global estimates of methane fluxes from deep sediments are still poorly constrained. Thus, Gas Hydrate Stability Zone thicknesses can be viewed as a proxy for potential hydrate deposits distribution but not necessarily for the real volume of hydrate-bearing sediments.
The aim of this study is to constrain the global inventory of methane hydrates in the seabed formed by the microbial degradation of organic matter within the GHSZ. For this purpose we explore the transport-reaction model that resolves for in-situ particular organic carbon (POC) degradation and hydrate formation and apply the model globally in a multi-1D mode. In contrast to previous attempts (Buffett and Archer, 2004; Archer and Buffett, 2005; Klauda and Sandler, 2005; Archer et al., 2008), the new model considers the down-core decrease in reactivity of organic matter (Middelburg, 1989; Wallmann et al., 2006). A validation of this approach was presented in the original paper by Wallmann et al. (2006) (Sea of Okhotsk and Blake Ridge) and by Marquardt et al. (2010) for a wide range of ODP sites (Costa Rica, Peru, Chile, California, Blake Ridge, and Namibia). We also introduce a new equation to calculate Holocene sedimentation rates as a function of water depth.

\section{INPUT DATA}

Global modeling requires global input data sets. We have compiled the necessary input data from a variety of different sources. To compute the global distribution of marine hydrate deposits all data sets are compiled on a $1^{\circ} \times 1^{\circ}$ resolution and presented in Electronic Annex (Figs. from EA-1 to EA-7).

Calculations of the GHSZ thicknesses are based on the global bathymetry (Fig. EA-1), salinity (Fig. EA-2), bottom water temperature (Fig. EA-3), and heat flow (Fig. EA-4) data. The first three data sets were extracted from an Ocean General Circulation Model (OGCM) simulation run in the ORCA_R025 configuration (Barnier, 2006). ORCA_R025 simulations were originally performed on a tri-polar mesh with a lateral resolution of $0.25^{\circ} \times 0.25^{\circ}$ and vertical resolution between 6 and $250 \mathrm{~m}$.

While temperature is a key parameter controlling hydrate stability, a global data set of geothermal gradients in marine sediments is unfortunately not available. We circumvent this problem by using available global heat flow data as a proxy to geothermal gradients. Sediment temperatures are assumed to be in steady-state and are computed from the global heat flow data provided by the International Heat Flow Commission (IHFC) (Hamza et al., 2008), bottom water temperatures extracted from the OGCM and a thermal conductivity $\kappa$ of $1.5 \mathrm{~W} \mathrm{~m}^{-1} \mathrm{~K}^{-1}$. This use of a constant thermal conductivity is, of course, a simplification. Grain conductivities of sedimentary rocks span a range of $\sim 1-6 \mathrm{~W} \mathrm{~m}^{-1} \mathrm{~K}^{-1}$ (Hantschel and Kauerauf, 2010) and the thermal conductivity of pore fluids is $\sim 0.6 \mathrm{~W} \mathrm{~m}^{-1} \mathrm{~K}^{-1}$ for a temperature range of $0-35^{\circ} \mathrm{C}$ (Deming and Chapman, 1989). The assumed constant value of $1.5 \mathrm{~W} \mathrm{~m}^{-1} \mathrm{~K}^{-1}$ is based on the geometrical average of pore water and matrix conductivities for a shaly-sandstone lithology.

A modified Pitzer-approach from Tishchenko et al. (2005) was used to calculate the depth-dependent solubility of gas hydrate and methane gas phases from the temperature profile, pressure, and salinity data. The intersection of solubility curves defines the bottom of the GHSZ and 
phase boundary between gas hydrates and free methane gas. Pore fluid salinity was set up to the global ocean values, neglecting potential local fluctuations caused by hydrate formation or dissociation processes. At many deep-sea locations the thickness of the GHSZ exceeds the thickness of sediments deposited at the seafloor. For these cases, the vertical extent of the GHSZ was reduced considering the available sediment thickness data. A combined set of global sediment thicknesses, mainly based on the global NOAA data (Divins, 2003) and arctic region data (Laske and Masters, 1997) with a maximum lateral resolution of $5^{\prime} \times 5^{\prime}$ was applied for this purpose (Fig. EA-5).

A key input parameter is the accumulation rate of particulate organic carbon (POC) in marine surface sediments. Both, POC concentrations in surface sediments and bulk sedimentation rates are needed to constrain this key parameter. The POC concentrations in surface sediments were implemented in the model according to the data set from Seiter et al. (2004) and Romankevich et al. (2009) with a maximum lateral resolution of $1^{\circ} \times 1^{\circ}$ (Fig. EA-6).

Unfortunately, sedimentation rates and burial velocities have not been measured and compiled for the global seafloor at suitable spatial resolution. Thus, water depth is often used as a proxy to estimate burial velocities (Middelburg, 1989). It is readily available for individual seafloor sites and for the global ocean. The burial velocity of Holocene surface sediments is reported for more than 500 stations in the compilations by Betts and Holland (1991), Colman and Holland (2000), and Seiter et al. (2004). These data clearly show that the burial velocity of Holocene surface sediments decreases with increasing water depth (Fig. 1).

A logistic equation (Eq. (1)) is applied to define the relationship between burial velocity ( $w$ in $\mathrm{cm} \mathrm{yr}^{-1}$ ) and water depth $(z$ in $\mathrm{m})$ :

$w=\frac{w_{1}}{1+\left(\frac{z}{z_{1}}\right)^{c 1}}+\frac{w_{2}}{1+\left(\frac{z}{z_{2}}\right)^{c 2}}$

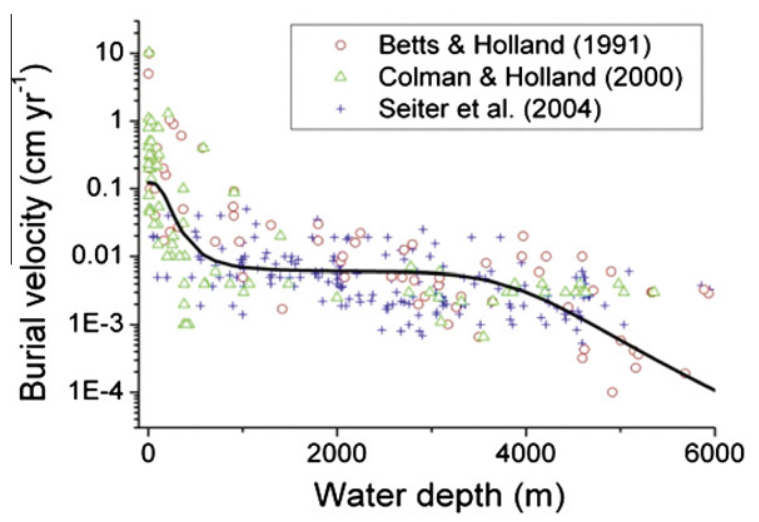

Fig. 1. Burial velocity of Holocene surface sediments. The data given by Betts and Holland (1991), Colman and Holland (2000) and Seiter et al. (2004) are shown as red dots, green triangles, and blue crosses, respectively. The solid line is defined by Eq. (1). (For interpretation of the references to color in this figure legend, the reader is referred to the web version of this article.)
The following set of parameter values was found to give the best fit to the three independent data sets shown in Fig. 1:

$$
\begin{array}{lll}
w_{1}=0.117 \mathrm{~cm} \mathrm{yr}^{-1} & w_{2}=0.006 \mathrm{~cm} \mathrm{yr}^{-1} & z_{1}=200 \mathrm{~m} \\
z_{2}=4000 \mathrm{~m} & c_{1}=3 & c_{2}=10
\end{array}
$$

Eq. (1) predicts that most of the sediment accumulation takes place on the continental shelves during the Holocene (see Table 1).

Soviet and Russian scientists compiled a large data set for modern sedimentation at the seafloor. Unfortunately, this data base is not available to the international scientific community. The mean sedimentation rates for different sediment types were, however, recently reported by Baturin (2007). The total amount of sediment being deposited at the seafloor as derived from that data set $\left(18.84 \times 10^{15} \mathrm{~g} \mathrm{yr}^{-1}\right.$, Baturin, $2007)$ is consistent with the values calculated from Eq. (1) $\left(19.56 \times 10^{15} \mathrm{~g} \mathrm{yr}^{-1}\right.$; see Table 1). The contribution of shelf and upper slope sediments $\left(13.6 \times 10^{15} \mathrm{~g} \mathrm{yr}^{-1}\right.$, Baturin, 2007) compares well with our estimate $\left(14.1 \times 10^{18} \mathrm{~g} \mathrm{yr}^{-1}\right.$, see Table 1). The validity of Eq. (1) may be further tested by considering independent data on the particle input to the global ocean compiled in Table 2. The global sediment accumulation rate derived from these data $(19.62 \times$ $10^{15} \mathrm{~g} \mathrm{yr}^{-1}$ ) is almost identical to the global rate derived from Eq. (1) $\left(19.56 \times 10^{15} \mathrm{~g} \mathrm{yr}^{-1}\right.$; see Table 1). It can thus be concluded that the overall rate and distribution of Holocene sediment accumulation is well represented by Eq. (1) (Fig. EA-7).

In many cases, the thickness of the GHSZ known from direct observations exceeds the depth of Holocene sediments by several orders of magnitude. Thus, mean sedimentation rates averaged over a period of several million years would be more appropriate for the prediction of hydrate accumulation than Holocene accumulation rates. During the Holocene, most riverine particles are deposited on the continental shelf because the shelf is not at isostatic equilibrium with the present sea level but is still affected by the much lower glacial sea level stand (Hay and Southam, 1977). The sea level was $120 \mathrm{~m}$ below its present value during the last glacial maximum (Rohling et al., 1998) reducing the water-covered shelf and marginal sea areas by approximately 50\% (Menard and Smith, 1966; Peltier, 1994; Ludwig et al., 1999). Under glacial conditions, the anomalous Holocene shelf accumulation rate may have been diminished by an order of magnitude (Hay, 1994) shifting the focus of sedimentation from the shelf to the continental rise and slope. Moreover, the transport of ice-rafted material and the deposition of eolian dust were strongly enhanced further increasing the accumulation rates at the margin seafloor (Lisitzin, 1996). Due to pressure conditions required for maintaining hydrate stability, gas hydrate accumulations occur only in margin sediments deposited at more than $300-350 \mathrm{~m}$ water depth on the continental slope and rise. The mean Quaternary sedimentation rate in this environment is certainly much higher than the Holocene value. The sediment accumulation at $200-3000 \mathrm{~m}$ water depth (Holocene value $2.73 \times 10^{15} \mathrm{~g} \mathrm{yr}^{-1}$; see Table 1) would increase by a factor of up to 5 if most of the Holocene shelf sedimentation $\left(14.1 \times 10^{15} \mathrm{~g} \mathrm{yr}^{-1}\right.$; see Table 1) 
Table 1

Depth distribution of sedimentation rates at the Holocene seafloor. Seafloor areas are taken from Menard and Smith (1966). Mean burial velocities over the indicated depth interval are calculated by numerical integration of Eq. (1). They are converted into sediment accumulation rates considering the seafloor areas listed in the second column and applying a sediment factor of $f_{\mathrm{S}}=d_{\mathrm{s}}(1-\phi)=0.5 \mathrm{~g} \mathrm{~cm}^{-3}$.

\begin{tabular}{lrcc}
\hline Water depth $(\mathrm{m})$ & $\begin{array}{c}\text { Seafloor area } \\
\left(10^{12} \mathrm{~m}^{2}\right)\end{array}$ & $\begin{array}{c}\text { Mean burial velocity } \\
\left(\mathrm{cm} \mathrm{yr}^{-1}\right)\end{array}$ & $\begin{array}{c}\text { Sediment accumulation rate } \\
\left(10^{15} \mathrm{~g} \mathrm{yr}^{-1}\right)\end{array}$ \\
\hline $0-200$ & 27.123 & 0.104 & 14.072 \\
$200-1000$ & 16.012 & 0.0163 & 1.308 \\
$1000-2000$ & 15.844 & 0.00635 & 0.503 \\
$2000-3000$ & 30.762 & 0.00598 & 0.919 \\
$3000-4000$ & 75.824 & 0.00463 & 1.754 \\
$4000-5000$ & 114.725 & 0.00155 & 0.892 \\
$5000-6000$ & 76.753 & 0.000278 & 0.107 \\
$6000-7000$ & 4.461 & $5.50 \times 10^{-5}$ & $1.23 \times 10^{-3}$ \\
$7000-11,000$ & 0.529 & $5.67 \times 10^{-6}$ & $1.50 \times 10^{-5}$ \\
Total & 362.033 & & 19.556 \\
\hline
\end{tabular}

Table 2

Global sediment accumulation rates at the seafloor. The values listed are valid for the pre-human Holocene.

\begin{tabular}{lll}
\hline & $\begin{array}{l}\text { Accumulation rate } \\
\left(10^{15} \mathrm{~g} \mathrm{yr}^{-1}\right)\end{array}$ & References \\
\hline Riverine particles & 14.0 & Syvitski et al. (2005) \\
Ice-rafted particles & 2.9 & Raiswell et al. (2006) \\
Dust & 0.45 & Jickells et al. (2005) \\
Shelf carbonate & 1.0 & Kleypas (1997) \\
Pelagic carbonate & 1.0 & Archer (1996) \\
Biogenic opal & 0.27 & Sarmiento and Gruber (2006) \\
Total & 19.62 & \\
\hline
\end{tabular}

was shifted to larger water depth under glacial conditions as proposed by Hay (1994). The hydrate accumulation model was thus run for two different scenarios. In the first scenario, we applied Holocene sedimentation rates calculated via Eq. (1). This run gives a minimum estimate of sediment and hydrate accumulation at the slope and rise. In the second scenario we increased the sedimentation rate at the distance from the continents of $<500 \mathrm{~km}$ by moving deposited material from shallow water depth $(0-200 \mathrm{~m})$ areas to continental slopes while the sedimentation rates at $(>500 \mathrm{~km})$ distance were maintained at the Holocene level defined by Eq. (1). This approach accounts for the Quaternary maximum sedimentation rates within continental margins. Thus, the total amount of sediments $\left(19.556 \times 10^{15} \mathrm{~g} \mathrm{yr}^{-1}\right.$; see Table 1) remains the same over the global ocean area.

\section{MATHEMATICAL MODEL}

\subsection{Introduction}

In order to constrain the global distribution and abundance of marine methane hydrates, we have developed a 1D numerical model simulating gas hydrate formation and dissolution processes in marine anoxic sediments and applied it globally in a multi-1D mode. The reactiontransport model is based on kinetically controlled rates of microbial POC degradation via sulfate reduction and methanogenesis. The system contains three dissolved compounds (methane $\left(\mathrm{CH}_{4}\right)$, dissolved inorganic carbon (DIC), sulfate $\left(\mathrm{SO}_{4}\right)$ ), two solid compounds (gas hydrate $(\mathrm{GH})$, particular organic carbon (POC)), and one gaseous compound (free methane gas (FG)). The model predicts concentration profiles for all chemical species and the total gas hydrate inventory of the considered sediment column.

Multi-1D modeling assumes a negligible effect of horizontal mass and energy exchange which is a reasonable assumption in this kind of sedimentary systems. All sets of single models were run until they reached steady-state conditions based on a steady amount of methane within the entire sediment column (scenario without hydrate formation), steady total mass of hydrates (hydrate and/or hydrate and free gas formation), or steady volume of methane gas (free gas formed alone).

To obtain a fine resolution of depth-dependent microbial, chemical, and kinetic reactions, each sediment column has been discretized with a centimeter scale numerical grid. The uppermost bioturbated part of sediment column was not considered in the model because of strongly variable gradients of chemical species concentrations.

\subsection{Reference frame}

Ocean basins and continental margins experience continuous vertical motion due to sedimentation and isostatic compensation processes. This makes the choice of reference frame essential. We consider a reference frame which 

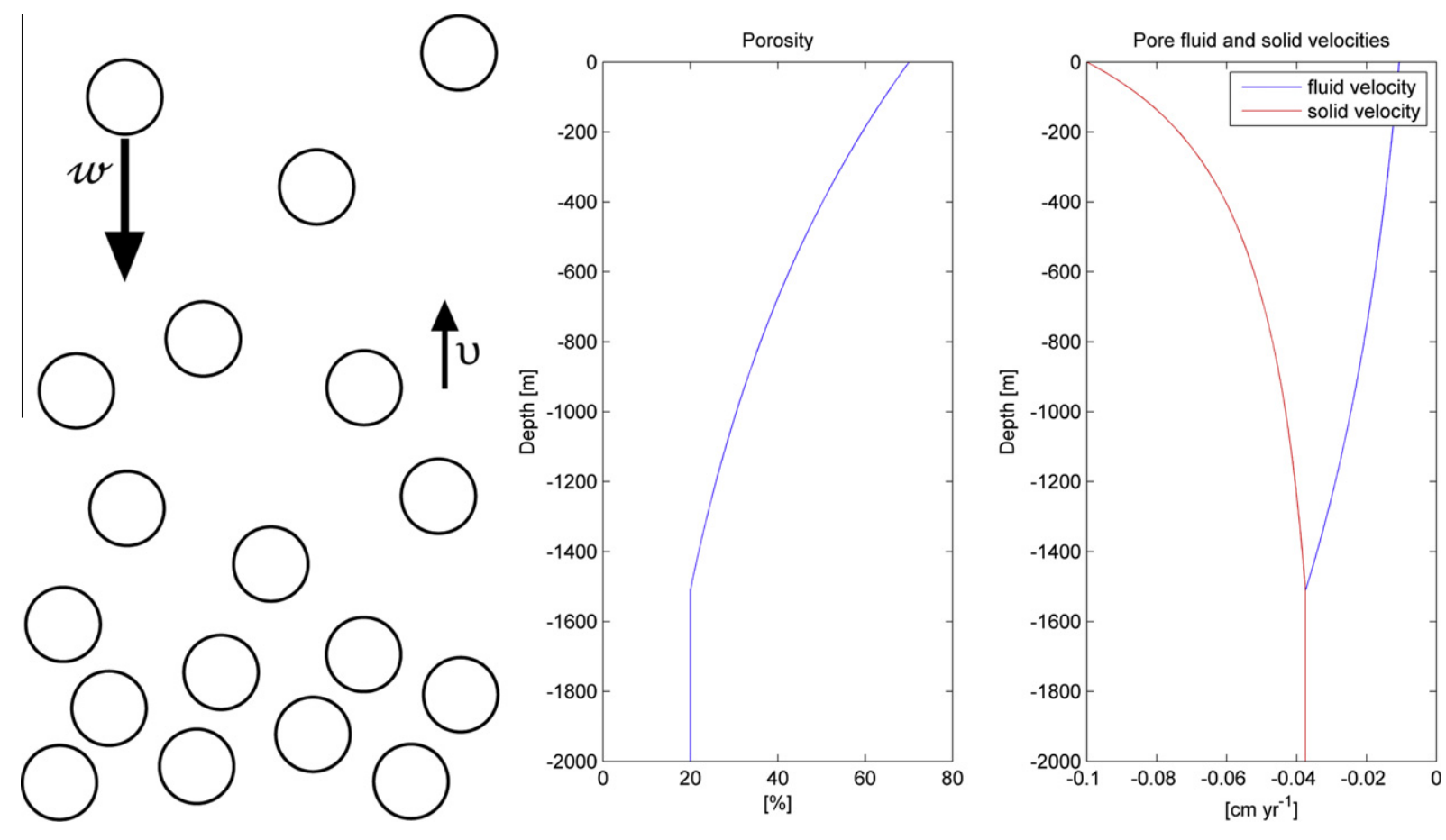

Fig. 2. An example of compaction-driven solid and fluid components movement within sediment column. Upward directed expulsion of fluids due to compaction processes provides a relative pore waters migration towards the seafloor, in relation to sediment grains (left panel). Progressing compaction results in depth-decreasing porosity (middle panel). Both solid and pore fluid velocities are directed downward in relation to the seafloor (right panel). Negative values of both velocities are the evidence of consequent downward movement of solid and fluid compounds. Gas phase included in the model is buried with sediment grains using the solid velocity.

extends from the seafloor to the bottom of the GHSZ plus $50 \mathrm{~m}$ of Free Gas Zone lying directly beneath. This implies that the spatial location of the upper boundary is fixed and does not follow sediment burial which results in a net downward migration of deposited sediments. The length of each sediment column is constant over time and is limited according to the global sediment thickness data. Therefore, the model column does not include the Free Gas Zone for those cases where the thickness of the GHSZ exceeds the sediment thickness. This fixed lower boundary results in the advective loss of system components through the bottom of the modeling domain.

Porosity, which decreases exponentially with depth, is calculated using Eq. (2) from Athy (1930) for the initial porosity $\phi_{0}$ and compaction length scale $c_{0}$. According to the reference frame, porosity remains constant at every grid point:

$\phi(z)=\phi_{0} \cdot \exp \left(c_{0} \cdot z\right)$

where $\phi$ is the porosity; $\phi_{0}$ is the initial porosity at the seafloor; $c_{0}$ is the compaction length scale $\left(\mathrm{cm}^{-1}\right) ; z$ is the depth $(\mathrm{cm})$.

\subsection{Compaction and advection velocities}

Sedimentation and compaction processes imply, in the chosen reference frame, a continuous downward movement of sediment grains with respect to the seafloor (Eq. (3)): $w(z)=\frac{-w_{0}\left(1-\phi_{0}\right)}{(1-\phi)}$

where $w$ is the burial velocity of solid species $\left(\mathrm{cm} \mathrm{yr}^{-1}\right) ; z$ is the depth $(\mathrm{cm}) ; w_{0}$ is the burial velocity at the upper boundary $\left(\mathrm{cm} \mathrm{yr}^{-1}\right) ; \phi_{0}$ is the initial porosity at the seafloor; $\phi$ is the porosity.

Burial velocity applied at the top of each model domain $\left(w_{0}\right)$ is taken from Eq. (1). Sediment compaction results in pore fluid pressurization and expulsion of pore fluids carrying dissolved chemical species (Fig. 2). In high permeability systems all excess pressures are released by relative upward flow; significant excess pressures can build up in systems of low permeability. Permeability is often correlated to porosity and may further be affected by hydrate content. Garg et al. (2008) reported that the size of sediment pores may affect the process of gas hydrate formation. The lithology of the potential hydrate-bearing zone (i.e. coarse-grained sands) may result in preferential hydrate accumulation. According to Darcy's law, high permeability allows for enhanced gas fluxes. However, a buffer effect caused by decreasing effective porosity due to formation of thick hydrate layers close to the bottom of the Gas Hydrate Stability Zone may block the advective free gas transport and support further hydrate accumulation within the lower part of GHSZ. These mechanisms are still poorly understood and were, thus, not considered in our model. Here we assume that permeability is always sufficiently high for pore fluids to be expelled by compaction. This allows us to use an analytical expression (Eq. (4)) for pore fluid flow (Hutchison, 1985): 
$w(z)=\frac{-w_{0}\left(1-\phi_{0}\right) \cdot \exp (z-B / \lambda)}{1-\phi_{0} \cdot \exp (-B / \lambda)}$

where $w$ is the burial velocity of solid species $\left(\mathrm{cm} \mathrm{yr}^{-1}\right) ; z$ is the depth $(\mathrm{cm}) ; w_{0}$ is the burial velocity at the upper boundary $\left(\mathrm{cm} \mathrm{yr}^{-1}\right) ; \phi_{0}$ is the initial porosity at the seafloor; $\phi$ is the porosity; $B$ is the basement depth $(\mathrm{cm}) ; \lambda=1 / c_{0}$ is the characteristic depth $(\mathrm{cm})$.

Basement of each sediment column $(B)$ from the fluid velocity equation was set to a value adequate for depths where porosity reaches the level of $20 \%$ and thus, compaction processes become negligible (see Table 3). Note that this equation solves for fluid flow with respect to the seafloor and flow is therefore always directed downwards but of lower magnitude than the solid velocity. A potential gas phase included in the model is buried with sediment grains using the solid velocity.

\subsection{Governing equations for solid and dissolved compounds}

Two major phases essential for gas hydrate formation were considered: liquid pore fluids containing dissolved chemical species $\left(\mathrm{CH}_{4}\right.$, DIC and $\left.\mathrm{SO}_{4}\right)$ and solids including incompressible sediment grains and particulate organic carbon. Free gas (formed due to hydrate recycling processes at the bottom of GHSZ or directly by POC degradation at great depths below the GHSZ) is attached to sediment grains and transported downward with solid phase velocity. Upward gas advection is thus neglected in the model since measurements in consolidated sediments indicate that gas migration occurs only if more than approximately $10 \%$ of the pore space is occupied by gas (Garg et al., 2008).

Transport of solid as well as dissolved compounds were solved as an advection process occurring via sediment burial into great depths with solid $(\omega)$ and fluid $(v)$ velocities. Dissolved chemical species are able to diffuse through the entire sediment profile according to their molecular diffusion coefficients scaled by tortuosity $\left(D_{\mathrm{s}}\right)$. Source terms contain time and depth-dependent rates of various chemical reactions (organic carbon decay $-R_{\mathrm{POC}}$, anaerobic oxidation of methane $-R_{\mathrm{AOM}}$, methanogenesis $-R_{\mathrm{M}}$, and sulfate reduction $-R_{\mathrm{SR}}$ ). Advection and diffusion processes have been split and solved separately for each component.

Eq. (5) describes mass conservation of solid species. The first term on the right-hand side represents the advective transport of solid compounds, while the second term accounts for all chemical reactions (Tables 4-6):

$(1-\phi) \cdot \frac{\partial G}{\partial \tau}=-\frac{\partial((1-\phi) \cdot w \cdot G)}{\partial z}+(1-\phi) \cdot R$

where $\phi$ is the porosity; $G$ is the concentration of solid species (wt. $\%) ; t$ is the time (yr); $w$ is the burial velocity of species $\left(\mathrm{cm} \mathrm{yr}^{-1}\right) ; z$ is the depth $(\mathrm{cm}) ; R$ is the chemical reaction rates $\left(\mathrm{wt} . \% \mathrm{yr}^{-1}\right)$.

Mass conservation of dissolved species is defined by Eq. (6) in which the first term on the right-hand side describes advective transport with the fluid velocity, the second one accounts for the molecular diffusion of dissolved species, and the last (source) term represents chemical reactions: $\phi \cdot \frac{\partial \mathrm{C}}{\partial t}=-\frac{\partial(\phi \cdot v \cdot \mathrm{C})}{\partial z}+\frac{\partial\left(\phi \cdot D_{\mathrm{s}} \cdot \frac{\partial \mathrm{C}}{\partial z}\right)}{\partial z}+\phi \cdot R$

where $\phi$ is the porosity; $\mathrm{C}$ is the concentration of dissolved species $(\mathrm{mM}) ; D_{\mathrm{s}}$ is the diffusion coefficients $\left(\mathrm{cm}_{2} \mathrm{yr}^{-1}\right) ; t$ is the time $(\mathrm{yr}) ; v$ is the burial velocity of dissolved species $\left(\mathrm{cm} \mathrm{yr}^{-1}\right) ; z$ is the depth $(\mathrm{cm}) ; R$ chemical reaction rates (wt. $\% \mathrm{yr}^{-1}$ ).

Dissolved species concentrations are calculated in mmol $\left.\mathrm{dm}^{-3}\right) \quad(\mathrm{mM})$ and subsequently converted into $\mathrm{mol} \mathrm{cm}{ }^{-3}$ to be consistent with depth $(\mathrm{cm})$ and volume $\left(\mathrm{cm}^{3}\right)$ units. Conversion factors of chemical reactions and gas hydrate and free gas formation rates are presented in tables after the modeling rate expressions (Tables 4 and 6).

Molecular diffusion of dissolved species is controlled by changes in concentration gradients. Diffusion coefficients of dissolved chemical compounds in sediments are calculated as molecular diffusion coefficients $\left(D_{\mathrm{m}}\right)$ for constant temperature $\left(2{ }^{\circ} \mathrm{C}\right)$ and salinity ( $\left.35 \mathrm{psu}\right)$ according to the equations from Boudreau (1997) scaled by tortuosity $\left(T_{\mathrm{o}}\right)$ from Boudreau (1996) (Eq. (7)):

$T_{\mathrm{o}}^{2}=1-2 \cdot \ln (\phi)$

where is the $T_{\mathrm{o}}$ is the tortuosity; $\phi$ is the porosity.

Diffusion coefficient of dissolved inorganic carbon was treated as a combination of $\mathrm{HCO}_{3}{ }^{-}$and $\mathrm{CO}_{2}$ (in 50:50 proportion) diffusivity which are the most wide-spread inorganic carbon carriers within marine anoxic sediments in close to neutral $\mathrm{pH}$ regimes.

\subsection{Reactions}

A key reaction is the degradation of organic matter (POC) which follows the kinetic approach developed by Wallmann et al. (2006) (Eq. (8)). This kinetic equation considers the decrease in organic matter reactivity with depth and age of sediments (Middelburg, 1989) and the inhibition of anaerobic degradation processes by the accumulation of dissolved metabolites in ambient pore fluids. Monod constant $K_{\mathrm{c}}$ describes the inhibition of organic matter decomposition by the concentration of $\mathrm{CH}_{4}$ and DIC. High values of $K_{\mathrm{c}}$ constant favor rapid POC decomposition and, consequently, gas hydrate formation:

$R_{\mathrm{POC}}=\frac{K_{\mathrm{c}}}{\mathrm{C}(\mathrm{DIC})+\mathrm{C}\left(\mathrm{CH}_{4}\right)+K_{\mathrm{c}}} \cdot k_{x} \cdot G(\mathrm{POC})$

where $R_{\mathrm{POC}}$ is the rate of POC degradation (wt. $\% \mathrm{yr}^{-1}$ ); $K_{\mathrm{c}}$ is the Monod inhibition constant $(\mathrm{mM}) ; k_{x}$ is the agedependent kinetic constant $\left(\mathrm{yr}^{-1}\right)$; $\mathrm{C}$ is the concentration of dissolved species ( $\mathrm{mM}$ )

A comparison of the new rate law with the classic Middelburg formulation showed that in mainly anoxic sediments with high concentrations of metabolites, Wallmann's kinetic equation results in diminished POC degradation rates that are in good agreement with pore water data obtained at ODP site 997 (Blake Ridge) and seven stations at Sakhalin slope (Sea of Okhotsk) (Wallmann et al., 2006). Subsequently, the Wallmann formulation was applied to a wide range of geological settings represented by ODP sites 1041 (Costa Rica), 685 and 1230 (Peru), 1233 
Table 3

Complete list of symbols and parameters used in the model formulation.

\begin{tabular}{|c|c|c|c|c|}
\hline Parameter & Description & Value & Units & Notes \\
\hline$B$ & Basement depth & - & $\mathrm{cm}$ & See description in text \\
\hline$C_{0}$ & Compaction length scale & $0.83 \times 10^{-5}$ & $\mathrm{~cm}^{-1}$ & - \\
\hline$n$ & Number of grid points in the modeling domain & 300 & - & - \\
\hline $\mathrm{T}_{\mathrm{o}}$ & Tortuosity & - & - & - \\
\hline$t$ & Time & - & yr & - \\
\hline$z_{0}$ & Seafloor & 0 & $\mathrm{~cm}$ & - \\
\hline$Z$ & Depth & - & $\mathrm{cm}$ & - \\
\hline$\lambda$ & Characteristic depth & - & $\mathrm{cm}$ & - \\
\hline$\kappa$ & Thermal conductivity & 1.5 & $\mathrm{~W} \mathrm{~m}^{-1} \mathrm{~K}^{-1}$ & - \\
\hline$\phi_{0}$ & Initial porosity & 0.7 & - & - \\
\hline$\phi$ & Porosity & - & - & - \\
\hline$v$ & Velocity of dissolved species & - & $\mathrm{cm} \mathrm{yr}^{-1}$ & - \\
\hline$w$ & Burial velocity of solid species & - & $\mathrm{cm} \mathrm{yr}^{-1}$ & - \\
\hline$w_{0}$ & Burial velocity at the upper boundary & - & $\mathrm{cm} \mathrm{yr}^{-1}$ & - \\
\hline $\mathrm{C}$ & Concentration of dissolved species & - & $\mathrm{mM}$ & - \\
\hline$G$ & Concentration of solid species & - & wt. $\%$ & - \\
\hline$D_{\mathrm{m}}$ & Molecular diffusion coefficient & - & $\mathrm{cm}^{2} \mathrm{yr}^{-1}$ & - \\
\hline$D_{\mathrm{s}}$ & Diffusion coefficient in sediments & - & $\mathrm{cm}^{2} \mathrm{yr}^{-1}$ & - \\
\hline $\mathrm{CH}_{4}$ (ini) & $\begin{array}{l}\text { Concentration of methane at the } \\
\text { upper boundary of model domain }\end{array}$ & $10^{-4}$ & $\mathrm{mM}$ & See description in text \\
\hline DIC(ini) & $\begin{array}{l}\text { Concentration of dissolved inorganic carbon } \\
\text { at the upper boundary of model domain }\end{array}$ & 4 & $\mathrm{mM}$ & See description in text \\
\hline $\mathrm{SO}_{4}$ (ini) & $\begin{array}{l}\text { Concentration of sulfates at the } \\
\text { upper boundary of model domain }\end{array}$ & 28.9 & $\mathrm{mM}$ & See description in text \\
\hline$R(X)$ & Change in chemical species concentrations & - & See Table 6 & See Table 6 \\
\hline$R_{\mathrm{POC}}$ & Rate of POC degradation & - & wt. $\% \mathrm{yr}^{-1}$ & See description in text \\
\hline$R_{\mathrm{AOM}}$ & Rate of anaerobic oxidation of methane & - & $\mathrm{mM} \mathrm{yr}^{-1}$ & See Table 4 \\
\hline$R_{\mathrm{M}}$ & Rate of methanogenesis & - & $\mathrm{mM} \mathrm{yr}^{-1}$ & See Table 4 \\
\hline$R_{\mathrm{SR}}$ & Rate of sulfate reduction & - & $\mathrm{mM} \mathrm{yr}^{-1}$ & See Table 4 \\
\hline$R_{\mathrm{GH}}$ & Rate of gas hydrate formation & - & wt. $\% \mathrm{yr}^{-1}$ & See Table 5 \\
\hline$R_{\mathrm{FG}}$ & Rate of free methane gas formation & - & wt. $\% \mathrm{yr}^{-1}$ & See Table 5 \\
\hline$R_{\mathrm{DGH}}$ & Rate of gas hydrate dissolution & - & wt. $\% \mathrm{yr}^{-1}$ & See Table 5 \\
\hline$R_{\mathrm{DFG}}$ & Rate of free methane gas dissolution & - & wt. $\% \mathrm{yr}^{-1}$ & See Table 5 \\
\hline$d_{\mathrm{s}}$ & Density of dry sediments & 2.65 & $\mathrm{~g} \mathrm{~cm}^{-3}$ & - \\
\hline$d_{\mathrm{GH}}$ & Gas hydrate density & 0.916 & $\mathrm{~g} \mathrm{~cm}^{-3}$ & - \\
\hline$d_{\mathrm{FG}}$ & Free methane gas density & - & $\mathrm{g} \mathrm{cm}^{-3}$ & See description in text \\
\hline $\mathrm{MW}_{\mathrm{C}}$ & Molecular weight of carbon & 12 & $\mathrm{~g} \mathrm{~mol}^{-1}$ & - \\
\hline $\mathrm{MW}_{\mathrm{GH}}$ & Molecular weight of gas hydrate & 124.13 & $\mathrm{~g} \mathrm{~mol}^{-1}$ & - \\
\hline $\mathrm{MW}_{\mathrm{FG}}$ & Molecular weight of free methane gas & 16 & $\mathrm{~g} \mathrm{~mol}^{-1}$ & - \\
\hline Vol & Molar volume of free methane gas & - & $\mathrm{cm}^{3} \mathrm{~mol}$ & See description in text \\
\hline $\mathrm{CH}_{4}{ }^{\text {diss }}$ & Solubility of dissolved methane & - & $\mathrm{mM}$ & See description in text \\
\hline $\mathrm{CH}_{4}^{4}$ free & Solubility of gaseous methane & - & $\mathrm{mM}$ & See description in text \\
\hline$K_{\mathrm{c}}$ & Monod inhibition constant of POC degradation & 47 & $\mathrm{mM}$ & See description in text \\
\hline$a_{0}$ & Initial age of organic matter decomposition & - & $\mathrm{yr}$ & See description in text \\
\hline$k_{x}$ & Age-dependent kinetic constant of POC degradation & - & $\mathrm{yr}^{-1}$ & See description in text \\
\hline$k_{\mathrm{AOM}}$ & Kinetic constant of methane oxidation & $10^{-8}$ & $\mathrm{mM}^{-1} \mathrm{yr}^{-1}$ & See Table 4 \\
\hline$K_{\mathrm{SO}_{4}}$ & Sulfate inhibition constant on methane formation & 1 & $\mathrm{mM}$ & See Table 4 \\
\hline$k_{\mathrm{GH}}$ & Kinetic constant of gas hydrate formation & $5 \times 10^{-3}$ & wt. $\% \mathrm{yr}^{-1}$ & See Table 5 \\
\hline$k_{\mathrm{FG}}$ & Kinetic constant of free methane gas formation & $10^{-3}$ & wt. $\% \mathrm{yr}^{-1}$ & See Table 5 \\
\hline$k_{\mathrm{DGH}}$ & Kinetic constant of gas hydrate dissolution & $2 \times 10^{-2}$ & $\mathrm{yr}^{-1}$ & See Table 5 \\
\hline$k_{\mathrm{DFG}}$ & Kinetic constant of free methane gas dissolution & $2 \times 10^{-4}$ & $\mathrm{yr}^{-1}$ & See Table 5 \\
\hline$f_{\mathrm{s}}$ & Sediment factor & 0.5 & $\mathrm{~g} \mathrm{~cm}^{-3}$ & See Table 1 \\
\hline$r_{\mathrm{c}}$ & Unit conversion factor & - & $\mathrm{cm}^{3} \mathrm{~mol}^{-1}$ & See Table 4 \\
\hline$r_{\mathrm{GH}}$ & Unit conversion factor & - & $\mathrm{cm}^{3} \mathrm{~mol}^{-1}$ & See Table 4 \\
\hline$r_{\mathrm{FG}}$ & Unit conversion factor & - & $\mathrm{cm}^{3} \mathrm{~mol}^{-1}$ & See Table 4 \\
\hline$r_{\mathrm{GH}}{ }^{\mathrm{vol}}$ & Unit conversion factor & - & - & See description in text \\
\hline$r_{\mathrm{FH}}{ }^{\text {vol }}$ & Unit conversion factor & - & - & See description in text \\
\hline
\end{tabular}

(Chile), 1014 (California), 995 (Blake Ridge), and 1084 (Namibia) (Marquardt et al., 2010). Required modeling parameters were taken directly from ODP reports and a good fit to the observed concentrations of dissolved metabolites accumulating in the pore fluids of the studied sediments was obtained applying a $K_{\mathrm{c}}$ value of $25-50 \mathrm{mM}$. Here, we 
Table 4

Details of the chemical reaction rates.

\begin{tabular}{ll}
\hline Rate & Kinetic rate law \\
\hline Anaerobic oxidation of methane $\left(\mathrm{mmol} \mathrm{yr}^{-1}\right)$ & $R_{\mathrm{AOM}}=K_{\mathrm{AOM}} \cdot \mathrm{C}\left(\mathrm{SO}_{4}\right) \cdot \mathrm{C}\left(\mathrm{CH}_{4}\right)$ \\
Methanogenesis $\left(\mathrm{mmol} \mathrm{yr}^{-1}\right)$ & $R_{\mathrm{M}}=0.5-\frac{K_{\mathrm{SO}_{4}}}{\mathrm{C}\left(\mathrm{SO}_{4}\right)+K_{\mathrm{SO}_{4}}} \cdot R_{\mathrm{POC}} \cdot r_{\mathrm{C}}$ \\
Sulfate reduction $\left(\mathrm{mmol} \mathrm{yr}^{-1}\right)$ & $R_{\mathrm{SR}}=0.5-\frac{\mathrm{C}\left(\mathrm{SO}_{4}\right.}{\mathrm{C}}\left(\mathrm{SO}_{4}\right)+K_{\mathrm{SO}_{4}} \cdot R_{\mathrm{POC} \cdot \mathrm{r}_{\mathrm{C}}}$ \\
Constant & Value \\
\hline$k_{\mathrm{AOM}}\left(\mathrm{dm}^{3} \mathrm{mmol}^{-1} \mathrm{yr}^{-1}\right)$ & $10^{8}$ \\
$K_{\mathrm{SO}_{4}}(\mathrm{mM})$ & 1 \\
$\mathrm{Conversion} \mathrm{factor}$ & Formulation \\
\hline$r_{\mathrm{C}}$ from $(\mathrm{wt} . \%)$ into $(\mathrm{mM})$ & $r_{\mathrm{C}}=\frac{\phi \cdot \mathrm{MW}_{\mathrm{C}}}{(1-\phi) \cdot d_{\mathrm{s}} \cdot 10^{4}}$ \\
& where \\
& $\phi$ is the porosity \\
& MW \\
& $d_{\mathrm{S}}$ is the density of dry sediments $\left(\mathrm{g} \mathrm{cm}{ }^{3}\right)$ \\
\hline
\end{tabular}

used a relatively high value of $47 \mathrm{mM}$ to allow for significant gas hydrate formation from in-situ POC degradation. Since microbial formation of methane remains only one of the multiple gas sources in marine sediments, our results should be considered as the minimum estimate of offshore gas hydrate deposits. The age-dependent kinetic constant $k_{x}$ was computed following a simple formulation assuming a depth-decreasing reactivity of metabolites (Eq. (9); see Middelburg, 1989):

$k_{x}=0.16 \cdot\left(\mathrm{a}_{0}+\frac{z}{w}\right)^{-0.95}$

where $k_{x}$ is the age-dependent kinetic constant $\left(\mathrm{yr}^{-1}\right) ; a_{0}$ is the initial age of organic matter decomposition (yr); $z$ is the depth $(\mathrm{cm}) ; w$ is the burial velocity of solid species $\left(\mathrm{cm} \mathrm{yr}^{-1}\right)$.

The upper boundary of each modeling domain is situated $10 \mathrm{~cm}$ below the real sediment surface where the effects of bioturbation and bioirrigation processes become negligible. Thus, the initial age of POC degradation from Eq. (9) represents time needed to reach the undisturbed sediments.

POC is degraded via microbial sulfate reduction until the dissolved sulfate pool in ambient pore waters is depleted (see Table 4). Below the sulfate penetration depth, POC is microbially decomposed into methane and $\mathrm{CO}_{2}$. Upward diffusing dissolved methane is consumed by anaerobic oxidation within the sulfate-methane transition zone. The rate of anaerobic oxidation of methane $\left(R_{\mathrm{AOM}}\right)$ depends on methane and sulfate concentrations in pore fluids and is additionally controlled by the kinetic constant $K_{\mathrm{AOM}}$ (see Table 4).

\section{GAS HYDRATE AND FREE GAS FORMATION}

Gas hydrate formation occurs wherever the dissolved methane concentration within the Gas Hydrate Stability Zone exceeds the critical saturation $\left(\mathrm{CH}_{4}{ }^{\text {diss }}\right)$. Free methane gas is formed below the GHSZ when dissolved methane concentrations exceed the free gas solubility $\left(\mathrm{CH}_{4}{ }^{\text {free }}\right)$. Hydrate $\left(R_{\mathrm{GH}}\right)$ and free gas formation $\left(R_{\mathrm{FG}}\right)$ rates are controlled by kinetic constants $k_{\mathrm{GH}}$ and $k_{\mathrm{FG}}$ preventing
Table 5

Rates of the gas hydrate and free gas formation and dissolution.

\begin{tabular}{|c|c|}
\hline Rate & Kinetic rate law \\
\hline $\begin{array}{l}\text { If } \mathrm{C}\left(\mathrm{CH}_{4}\right) \geqslant \mathrm{CH}_{4}{ }^{\text {diss }} \\
R_{\mathrm{CH}}\left(\text { wt. } \% \mathrm{yr}^{-1}\right)\end{array}$ & $R_{\mathrm{GH}}=k_{\mathrm{GH}} \cdot\left(\frac{\mathrm{C}_{\left(\mathrm{CH}_{4}\right)}}{\mathrm{CH}_{4}{ }_{4} \mathrm{iss}}-1\right)$ \\
\hline $\begin{array}{l}\text { If } \mathrm{C}\left(\mathrm{CH}_{4}\right)<\mathrm{CH}_{4}{ }^{\text {diss }} \\
R_{\mathrm{DGH}}\left(\mathrm{wt}_{0} \% \mathrm{yr}^{-1}\right)\end{array}$ & $R_{\mathrm{DGH}}=k_{\mathrm{DGH}} \cdot\left(1-\frac{\mathrm{C}_{\left(\mathrm{CH}_{4}\right)}}{\mathrm{CH}_{4}{ }^{\text {diss }}}\right) \cdot \mathrm{G}(\mathrm{GH}$ \\
\hline $\begin{array}{l}\text { If } \mathrm{C}\left(\mathrm{CH}_{4}\right) \geq \mathrm{CH}_{4} \text { free } \\
R_{\mathrm{FG}}\left(\mathrm{wt} \% \mathrm{yr}^{-1}\right) \\
\text { If } \mathrm{C}\left(\mathrm{CH}_{4}\right)<\mathrm{CH}_{4}{ }^{\text {free }}\end{array}$ & $R_{\mathrm{FG}}=k_{\mathrm{FG}} \cdot\left(\frac{\mathrm{C}\left(\mathrm{CH}_{4}\right)}{\mathrm{CH}_{4}{ }^{\text {fee }}}-1\right)$ \\
\hline$R_{\mathrm{DFG}}\left(\mathrm{wt} . \% \mathrm{yr}^{-1}\right)$ & $R_{\mathrm{DFG}}=k_{\mathrm{DFG}} \cdot\left(1-\frac{\mathrm{c}\left(\mathrm{CH}_{4}\right)}{\mathrm{CH}_{4} \mathrm{free}}\right) \cdot \mathrm{G}(\mathrm{FG})$ \\
\hline Constant & Value \\
\hline$\overline{k_{\mathrm{GH}}\left(\mathrm{wt}_{\mathrm{C}} \% \mathrm{yr}^{-1}\right)}$ & $5 \times 10^{-3}$ \\
\hline$k_{\mathrm{DGH}}\left(\mathrm{yr}^{-1}\right)$ & $2 \times 10^{-2}$ \\
\hline$k_{\mathrm{FG}}\left(\mathrm{wt}_{0} \% \mathrm{yr}^{-1}\right)$ & $10^{-3}$ \\
\hline$k_{\mathrm{DFG}}\left(\mathrm{yr}^{-1}\right)$ & $10^{-4}$ \\
\hline
\end{tabular}

over-saturations (see Table 5). Hydrate and free gas are dissolved in undersaturated pore fluids. Dissolution rates ( $R_{\mathrm{DGH}}$ and $R_{\mathrm{DFG}}$ ) depend on saturation states with respect to hydrate and free gas and are mediated by corresponding kinetic constants (see Table 5) Dissolved methane is able to form either gas hydrates $\left(\mathrm{CH}_{4} \leftrightarrow \mathrm{GH}\right)$, free gas $\left(\mathrm{CH}_{4} \leftrightarrow \mathrm{FG}\right)$ or both at the same time, and vice versa. A modified Pitzer-approach from Tishchenko et al. (2005) is used to calculate the solubility curves of the mentioned phases for a wide range of temperature, pressure, and salinity values.

The rates of microbial and chemical reactions as well as rates of hydrate and free gas formation and dissolution processes were consequently updated after each time step according to the formulations listed in Table 6.

Gas hydrate and free gas formation rates were finally converted from wt.\% into vol \% units by using the $r_{\mathrm{GH}}{ }^{\mathrm{vol}}$ and $r_{\mathrm{FH}}{ }^{\mathrm{vol}}$ factors (Eqs. (10) and (11)):

$r_{\mathrm{GH}}{ }^{\mathrm{vol}}=\frac{(1-\phi) \cdot d_{\mathrm{s}}}{\phi \cdot d_{\mathrm{GH}}}$

$r_{\mathrm{FH}}{ }^{\mathrm{vol}}=\frac{(1-\phi) \cdot d_{\mathrm{s}}}{\phi \cdot d_{\mathrm{FG}}}$ 
Table 6

Change in chemical species concentrations $R(\mathrm{X})$ due to chemical reactions. Factor $r_{\mathrm{c}}$ used in the POC unit conversion has been described in Table 4 .

\begin{tabular}{|c|c|}
\hline Solid species (wt.\%) & Rate expression $\left(\mathrm{wt}^{2} \% \mathrm{yr}^{-1}\right)$ \\
\hline Particular organic carbon (POC) & $R(\mathrm{POC})=-R_{\mathrm{POC}}$ \\
\hline Gas hydrate $(\mathrm{GH})$ & $R(\mathrm{GH})=R_{\mathrm{GH}}-R_{\mathrm{DGH}}$ \\
\hline Dissolved species (mM) & Rate expression (wt. $\% \mathrm{yr}^{-1}$ ) \\
\hline Methane $\mathrm{CH}_{4}$ & $R\left(\mathrm{CH}_{4}\right)=R_{\mathrm{M}}-R_{\mathrm{AOM}}-\left(R_{\mathrm{GH}}+R_{\mathrm{DGH}}\right) / r_{\mathrm{GH}}-\left(R_{\mathrm{FG}}+R_{\mathrm{DFG}}\right) / r_{\mathrm{FG}}$ \\
\hline Dissolved inorganic carbon (DIC) & $R(\mathrm{DIC})=R_{\mathrm{POC}} / r_{\mathrm{C}}+R_{\mathrm{AOM}}-R_{\mathrm{M}}$ \\
\hline Sulfates $\left(\mathrm{SO}_{4}\right)$ & $R\left(\mathrm{SO}_{4}\right)=-R_{\mathrm{SR}}-R_{\mathrm{AOM}}$ \\
\hline Gaseous species (wt.\%) & Rate expression (wt. $\% \mathrm{yr}^{-1}$ ) \\
\hline Free methane gas $(\mathrm{FG})$ & $R(\mathrm{FG})=R_{\mathrm{FG}}-R_{\mathrm{DFG}}$ \\
\hline Conversion factor & Formulation \\
\hline \multirow[t]{4}{*}{$r_{\mathrm{GH}}$ from $(\mathrm{wt} . \%)$ into $(\mathrm{mM})$} & $\begin{array}{l}r_{\mathrm{GH}}=\frac{\phi \cdot \mathrm{MW}_{\mathrm{GH}}}{(1-\phi) \cdot d_{s} \cdot 10^{4}} \\
\text { where }\end{array}$ \\
\hline & $\phi$ is the porosity \\
\hline & $\mathrm{MW}_{\mathrm{GH}}$ is the molecular weight of gas hydrate $\left(\mathrm{g} \mathrm{mol}^{-1}\right)$ \\
\hline & $d_{\mathrm{s}}$ is the density of dry sediments $\left(\mathrm{g} \mathrm{cm}^{3}\right)$ \\
\hline \multirow[t]{3}{*}{$r_{\mathrm{FG}}$ from $(\mathrm{wt} . \%)$ into $(\mathrm{mM})$} & $\begin{array}{l}r_{\mathrm{FG}}=\frac{\phi \cdot \mathrm{MW}_{\mathrm{FG}}}{(1-\phi) \cdot d_{\mathrm{s}} \cdot 10^{4}} \\
\text { where }\end{array}$ \\
\hline & $\phi$ is the porosity \\
\hline & $\mathrm{MW}_{\mathrm{FG}}$ is the molecular weight of methane gas $\left(\mathrm{g} \mathrm{mol}^{-1}\right)$ \\
\hline
\end{tabular}

where $\phi$ is the porosity; $d_{\mathrm{s}}$ is the density of dry sediments $\left(\mathrm{g} \mathrm{cm}^{-3}\right) ; d_{\mathrm{GH}}$ is the density of gas hydrate $\left(\mathrm{g} \mathrm{cm}^{-3}\right) ; d_{\mathrm{FG}}$ is the density of methane gas $\left(\mathrm{g} \mathrm{cm}^{-3}\right)$.

Apart from gas hydrate density $d_{\mathrm{GH}}$ which was set to a constant value of $0.916 \mathrm{~g} \mathrm{~cm}^{-3}$ according to Wallmann et al. (2006), significant changes of temperature and pressure conditions due to increasing depth are important in free methane gas density $d_{\mathrm{FG}}$ calculations. By using the Eq. (12) a depth-dependent free gas density profile was incorporated into our model:

$d_{\mathrm{FG}}=\frac{\mathrm{MW}_{\mathrm{FG}}}{\mathrm{Vol}}$

where $d_{\mathrm{FG}}$ is the density of methane gas $\left(\mathrm{g} \mathrm{cm}^{-3}\right)$; $\mathrm{MW}_{\mathrm{FG}}$ is the molecular weight of methane gas $\left(\mathrm{g} \mathrm{cm}^{-1}\right)$; $\mathrm{Vol}$ is the molar volume of methane gas $\left(\mathrm{cm}^{3} \mathrm{~mol}\right)$.

Calculations of pure methane gas molar volume ( $\mathrm{Vol})$ at various temperature, pressure, and fugacity coefficients were based on equations given in Tishchenko et al. (2005).

\section{NUMERICAL PROCEDURE}

As boundary conditions we assume constant concentrations of dissolved methane, dissolved inorganic carbon, and sulfate at the top of each modeled sediment column according to the mean concentrations observed at the bottom of the bioturbated zone (see Table 3). POC concentrations at the upper boundary of the model columns were set to the ambient values given by Seiter et al. (2004) and Romankevich et al. (2009). Burial velocities at zero depth $\left(w_{0}\right)$ were defined as a function of water depth applying Eq. (1). As discussed in a Section 3, in a second model run, $w_{0}$ values were enhanced by a factor of 5 along continental margins to estimate Quaternary burial velocities. Zero concentration gradients were applied at the lower boundary of the model column.

At modeling time zero sediment pore space was filled by pore fluids with salinity values consistent with the one at the sediment-water interface. The initial concentrations in the uppermost segment of the model column were defined according to the upper boundary conditions. Within the sediment column, the initial concentrations of POC, dissolved methane and DIC were set to zero while a simple exponential function was applied to define the down-core decrease in initial dissolved sulfate concentrations. Pressure regimes were calculated separately for each sediment bin as hydrostatic pressure values considering ambient water and sediment depths. Temperature profiles are set according to the bottom water temperature and heat flow data.

The governing diffusion-advection equations are solved using an operator-splitting technique. Diffusion is solved using a fully-implicit finite-differences method. Advection is solved by a Semi-Lagrangian scheme using linear interpolation functions. The update of all concentration profiles is sequential: during every time step, first the reaction rates are computed, next the transport parts of all equations are solved, and finally the diffusion parts. All chemical reactions are treated as source terms in the diffusion solver. The entire model was implemented in Matlab 7.7.0 (R2008b).

\section{RESULTS AND DISCUSSION}

\subsection{Global gas hydrate distribution}

We have analyzed two scenarios of low and high sedimentation which represent minimum and maximum 
estimates of hydrate accumulation via microbial methane formation within the GHSZ.

In the low sedimentation rate scenario we explored the dynamics of hydrate formation under Holocene boundary conditions. The total amount of methane carbon from hydrates is estimated to be $\sim 4.18 \mathrm{Gt}$. Gas hydrate deposits are distributed mostly in the Central America and Arctic region with concentrations not exceeding $150 \mathrm{~kg} \mathrm{C} \mathrm{m}^{-2}$. Our results show that widespread hydrate formation based on in-situ POC degradation is very unlikely to occur due to low burial velocities of particulate organic matter. The amount of dissolved methane is usually too small to exceed the $\mathrm{CH}_{4}$ solubility curve which is the critical step for hydrate precipitation. This model result clearly shows that hydrate formation is severely limited by low sedimentation rates at the continental slope and rise. Trapping of terrigenous particles in the shelf environment, thus, effectively inhibits hydrate formation via microbial POC degradation within the GHSZ under Holocene boundary conditions (Wallmann et al., 2006).

The Quaternary sedimentation conditions applied in the second scenario result in significant and wide-spread gas hydrate accumulations along active and passive continental margins (i.e. western and eastern coasts of North and South America). Hydrates are also formed in parts of the Indian Ocean, the Arctic Ocean, the Southern Ocean and the equatorial Pacific (see Fig. 3). Total amount of methane gas trapped within hydrate-bearing sediments in the high sedimentation scenario is estimated at $\sim 2.10 \times 10^{15} \mathrm{~m}^{3}$ (expanded to atmospheric conditions) or, equivalently, 995 Gt of methane carbon. This value is in good agreement with predictions of 500-2500 Gt of carbon presented by Milkov (2004) based on field observations.

The highest gas hydrate concentrations (up to 830 $\mathrm{kg} \mathrm{C} \mathrm{m}{ }^{-2}$ ) are observed in regions of high organic carbon accumulation (Fig. EA-6), i.e. Central America, eastern coast of South America, Laptev Sea, and Arabian Sea and do not correlate in a simple way with GHSZ thicknesses (Fig. 4). For up to $0.5 \%$ of the total number of hydrate-bearing modeling domains gas hydrate concentrations exceed $400 \mathrm{~kg} \mathrm{C} \mathrm{m}^{-2}$ (i.e. Central America, Arctic, and Arabian Sea). Gas hydrates have been previously documented at various cold seeps (Schmidt et al., 2005) and ODP sites along the central American margin (Hensen and Wallmann, 2005). Moderate hydrate concentrations $\left(150-400 \mathrm{~kg} \mathrm{C} \mathrm{m}^{-2}\right.$ ) occur at $\sim 8.5 \%$ of total hydrate provinces (western and eastern coasts of North America, Arctic, Sea of Okhotsk, Antarctic, eastern coast of Australia, Africa continental margin, Indian Ocean, Central America, and eastern coast of Greenland). The remaining regions of hydrate accumulation feature low hydrate saturations $\left(<150 \mathrm{~kg} \mathrm{C} \mathrm{m}^{-2}\right)$.

One of the first model-based estimates of the global methane hydrate inventory was presented by Buffett and Archer (2004). They used the rain rate of particulate organic carbon (POC) to the seabed as a major external driving force for the simulation of hydrate formation in marine sediments. The rain rate was calculated as a function of water depth and applied as an upper boundary condition for an early diagenesis model simulating the degradation of POC in the top meter of the sediment column (Archer et al., 2002). The POC burial rate at $1 \mathrm{~m}$ sediment depth calculated with this "muds" model was applied as an upper boundary condition for the simulation of methane turnover in the underlying sediment sequence. The later simulations consider the microbial degradation of POC via sulfate reduction and methanogenesis and the anaerobic oxidation of methane within the sulfate-methane transition zone (Davie and Buffett, 2001, 2003). POC was separated into an inert fraction and a labile fraction that was degraded over the top $\mathrm{km}$ of the sediment column following first order reaction kinetics (rate constant $3 \times 10^{-13} \mathrm{~s}^{-1}$ ). The model also considers an externally imposed rate of upward fluid flow. It was calibrated using field data obtained at Blake Ridge (a passive margin site) and the Cascadia margin (active continental margin). The best fit to observations
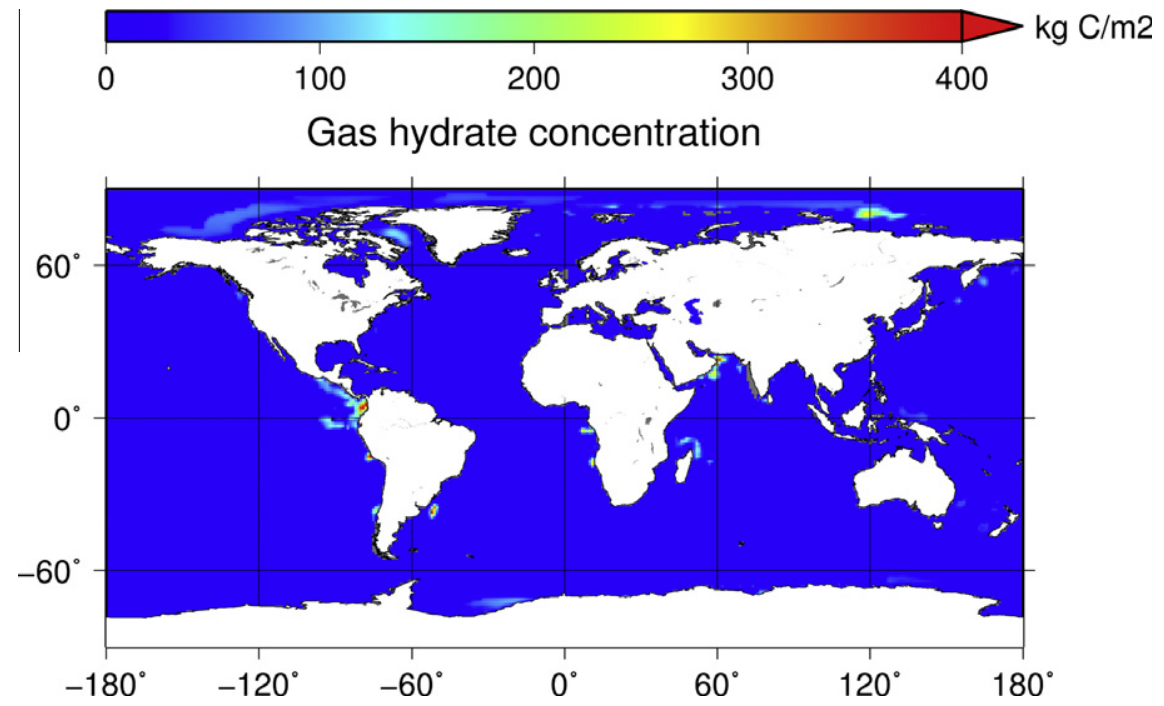

Fig. 3. Global distribution of gas hydrates under Quaternary sedimentation conditions. For the open ocean sedimentation rates are calculated according to Eq. (1); sedimentation close to continents $(<500 \mathrm{~km})$ is enhanced by a factor of five. 

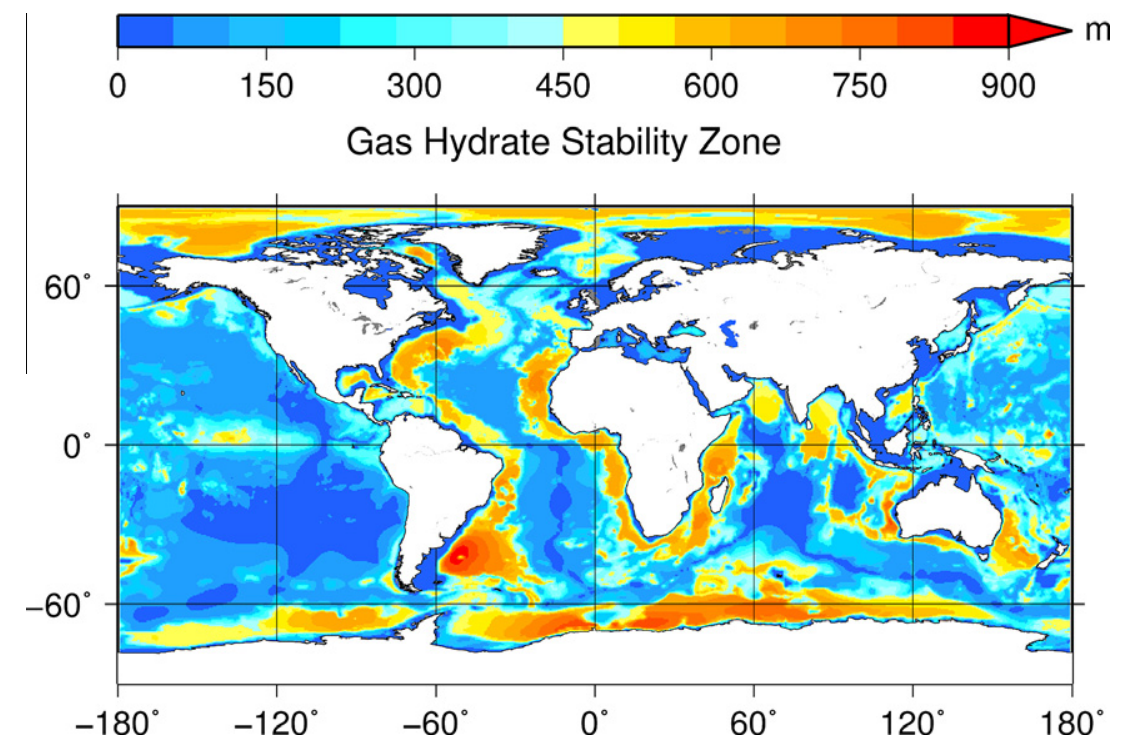

Fig. 4. Predicted thickness of the Gas Hydrate Stability Zone (GHSZ).

was obtained assuming that the $25 \%$ of the total POC is labile and using upward fluid flow velocities of $0.23 \mathrm{~mm} \mathrm{yr}^{-1}$ (passive margin) to $0.4 \mathrm{~mm} \mathrm{yr}^{-1}$ (active margin). Applying these parameter values on a global grid and assuming a compensating downward fluid flow over $50 \%$ of the global seafloor area resulted in a total methane hydrate inventory of $3000 \mathrm{Gt} \mathrm{C}$ (Buffett and Archer, 2004). The hydrate inventory was to a large degree controlled by the velocity of upward fluid flow that was assumed to exceed the flow rate induced by sediment compaction by $20 \%$ (passive margins) to $60 \%$ (active margins). Without imposed fluid flow, the global hydrate inventory was reduced to $600 \mathrm{Gt} \mathrm{C}$ (Buffett and Archer, 2004). Subsequently, the authors discovered an extrapolation error in the calculation of POC rain rates as function of water depth (Archer et al., 2008). The modelbased estimate of the global hydrate inventory was reduced from $3000 \mathrm{Gt} C$ to approximately $700-900 \mathrm{Gt} \mathrm{C}$ after correction for this error (Archer et al., 2008).

Klauda and Sandler (2005) used a slightly modified version of the Davie and Buffett model (Davie and Buffett, 2001) to estimate the global marine hydrate inventory. The entire POC pool was assumed to be completely degradable with a reduced decay constant of only $1.5 \times 10^{-14} \mathrm{~s}^{-1}$. In contrast to Buffett and Archer (2004) and Archer et al. (2008), the upper boundary of the model domain was constrained by field data. POC concentrations measured in surface sediments and Holocene sedimentation rates averaged over the major ocean basins were applied to define the POC burial flux at the sediment surface (Klauda and Sandler, 2005). In contrast to the study of Buffett and Archer (2004) and the one presented in this paper, the numerical approach of Klauda and Sandler (2005) does not consider organic matter degradation via sulfate reduction processes. Thus, efficient methane production in the upper part of the sediment column is not inhibited by the presence of dissolved sulfate. The Klauda and Sandler (2005) model was run without imposing upward fluid flow. This global hy- drate inventory of $\sim 57,000 \mathrm{Gt} \mathrm{C}$ was calculated applying the $1 \mathrm{D}$ model to a global grid. This estimate considers only the hydrate formed by POC degradation within the GHSZ. It is almost two orders of magnitude higher than our estimate of the global hydrate inventory and the estimate presented by Archer et al. (2008). This large difference may be explained by the neglect of microbial sulfate reduction and AOM since the accumulation of methane in pore fluids and gas hydrates is strongly diminished by these processes. Moreover, Buffett and Archer (2004) and Klauda and Sandler (2005) applied the thermodynamic equilibrium model between gas hydrate, sea water, and methane gas phases presented by Zatsepina and Buffett (1998), whereas our model is based on the study presented by Tishchenko et al. (2005). The latter approach considers the measured $\mathrm{CH}_{4}$ solubility in seawater and is in good agreement with other published data (Duan et al., 1992).

The commercial recovery potential of gas hydrate resources strongly depends on the type of clathrate accumulations. Stratigraphic-type of deposits (Milkov and Sassen, 2002) usually contain highly dispersed hydrocarbons of limited economic value. However, structural gas hydrate accumulations associated with high hydrocarbon fluxes from deep origin might have an economic potential as they are able to hold a large volume of methane gas concentrated in gas hydrates (Milkov and Sassen, 2002). Comparatively, the world's conventional gas endowment which is estimated at 2.567 TBOE (Trillion Barrels of Oil Equivalent) equivalent to $436.4 \times 10^{12} \mathrm{~m}^{3}$ of natural gas (USGS World Energy Assessment Team, 2000), is at least a few times smaller than the global methane hydrate inventory calculated in our Quaternary simulation. It should, however, be noted that the simulation results and the global inventories presented in this study are only valid for finely dispersed gas hydrates (stratigraphic type of deposits).

Significant hydrocarbon fluxes from a deep origin are well-known to occur in many important gas hydrate 

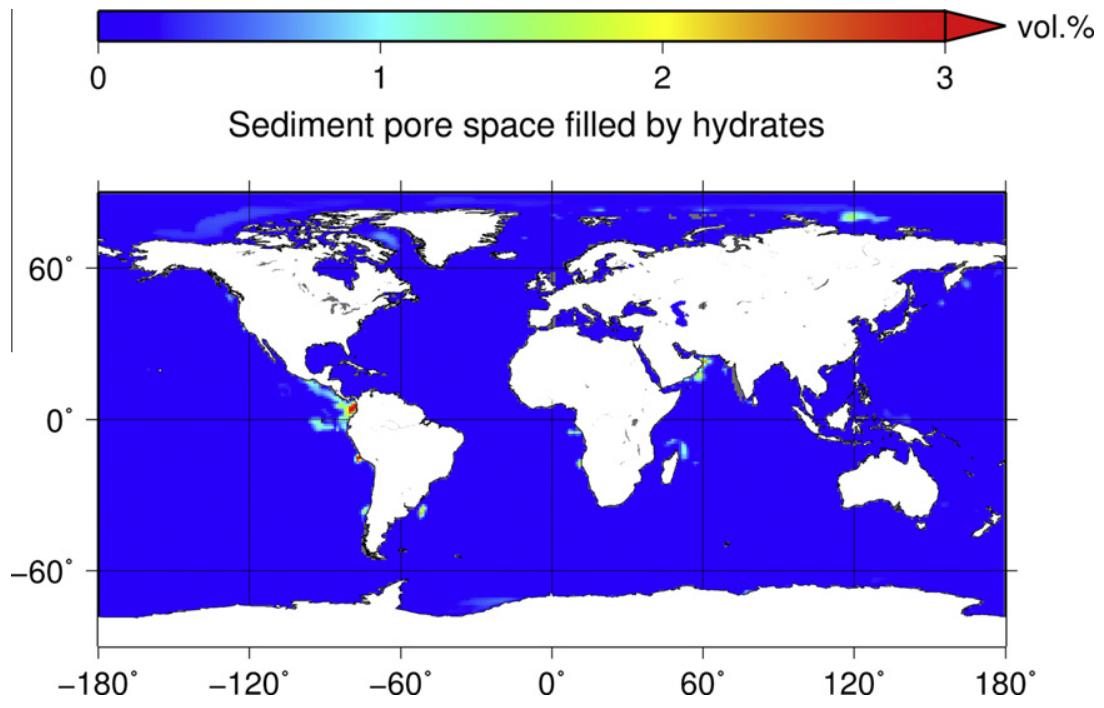

Fig. 5. Predicted filling of pore space by gas hydrate in the high sedimentation scenario.

provinces, i.e. the Gulf of Mexico or Hydrate Ridge (Torres et al., 2004; Liu and Flemings, 2006). Gas hydrate deposits associated with active faults and craters of deep-water mud volcanoes usually present higher gas hydrate concentrations (30-50\% of the pore space is filled by hydrates according to Milkov and Sassen (2002)). Comparatively, stratigraphic types of accumulations located within passive margins are characterized by relatively low advective fluid fluxes and low hydrate concentrations (5-10\% of the pore space is filled by hydrates according to Xu and Ruppel (1999)).

The locations and abundance of deep methane sources are still under discussion and were not taken into account in our investigations. Fig. 5 presents the average pore-space filled by gas hydrates for the high sedimentation scenario. The highest fractions of the total pore space occupied by hydrates $(10-12 \%)$ are characteristic of regions with relatively shallow water depths and high organic carbon content. Mean hydrate saturations calculated by our model approach do not exceed $2-4 \%$ of the total pore space.

\subsection{Controls on gas hydrate formation}

Gas hydrates are able to precipitate in porous media situated within the Gas Hydrate Stability Zone (GHSZ) which is defined by ambient pressure, temperature, and salinity conditions. Gas hydrate and free gas solubility curves calculated by the thermodynamic model of Tishchenko et al. (2005) intersect at the lower boundary of the GHSZ. This vertical extent of the GHSZ is limited by sediment thickness for up to $38 \%$ of the total world ocean surface. Thus, it can be suggested that a significant part of the global hydrate stability field in marine settings extends to the bottom of oceanic sediments. Free gas is thus not stable and present in many pelagic open ocean settings.

Gas Hydrate Stability Zones of significant thicknesses $(600-800 \mathrm{~m})$ are mainly situated in high-latitude regions (Arctic and Antarctic) due to low bottom water temperatures which maintain conditions required for hydrate

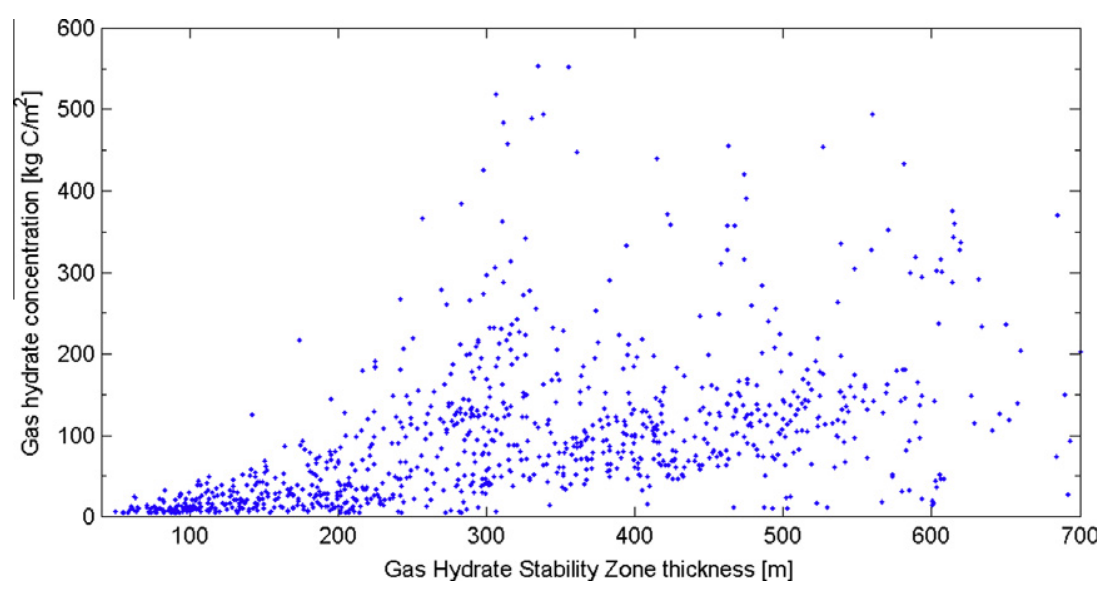

Fig. 6. Relationship between Gas Hydrate Stability Zone (GHSZ) thickness and gas hydrate concentration for high sedimentation scenario. A correlation for relatively thin stability zones could be observed (see further description in text). 


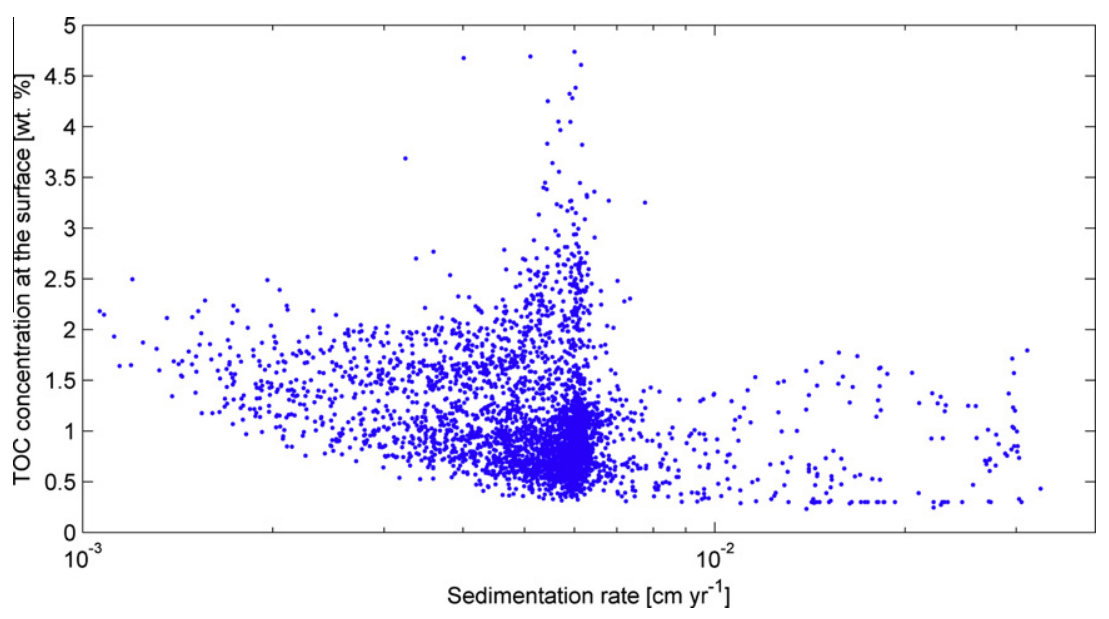

Fig. 7. TOC concentration at the surface as a function of sedimentation rate shows the minimum amount of organic matter needed for gas hydrate formation in the high sedimentation scenario (see further description in text).

formation. Extended GHSZs are also observed along continental margins $(>500 \mathrm{~m})$ where thick sedimentary sequences are deposited. In these settings the extent of the GHSZ is not limited by sediment thickness such that free gas accumulates in sediments below the GHSZ.

Fig. 6 presents a relationship between thickness of GHSZ and depth-integrated hydrate concentration for the high sedimentation scenario. Presented data include all modeling domains where gas hydrates accumulate. For relatively low GHSZ thicknesses a delicate trend of increasing hydrate concentrations could be observed. However, moderate and large GHSZ thicknesses $(>200-220 \mathrm{~m})$ do not correlate in a simple way with the amount of hydrates. Under these conditions, simulated hydrate accumulations largely depend on the supply of methane via in-situ organic matter degradation.

The availability of organic carbon at the seafloor is thought to be one of the most essential parameters limiting gas hydrate formation (Revelle, 1983; Kvenvolden, 1988; Klauda and Sandler, 2005). The minimum concentration of TOC necessary to initiate and sustain hydrate precipitation was suggested to be larger than $1 \mathrm{wt} . \%$ (Kvenvolden, 1988), 0.5 wt.\% (Revelle, 1983). We suggest that hydrate formation is not controlled by concentration of organic carbon but rather by the combination of TOC concentration and sedimentation rate. Fig. 7 presents the relationship between rates of sedimentation and organic matter concentration for our high sedimentation scenario. All grid points where hydrates accumulate are included in this figure whereas grid points without hydrate accumulation are excluded. The minimum amount of TOC needed to form gas hydrates is around $0.3 \mathrm{wt} . \%$ for high sedimentation rates and relatively shallow water depths $(\sim 250 \mathrm{~m})$. This threshold value increases with decreasing sedimentation rate and reaches a value of $>1.0 \mathrm{wt} . \%$ at low sedimentation rates $\left(\sim 1 \mathrm{~cm} \mathrm{kyr}^{-1}\right)$ characteristic for large water depths and open ocean settings. The TOC concentration threshold for hydrate formation is thus not a fixed value but a function of sedimentation rate.

\section{CONCLUSIONS}

Using our approach the world's total inventory of gas hydrates is estimated at $0.82 \times 10^{13} \mathrm{~m}^{3}-2.10 \times 10^{15} \mathrm{~m}^{3}$ $\mathrm{CH}_{4}$ (at STP conditions) or, equivalently, 4.18-995 Gt of methane carbon. The low estimate corresponds to the Holocene sedimentation scenario, while the high estimate refers to a scenario of higher Quaternary sedimentation at continental slope and rise settings. These estimates are significantly lower than previously reported values and are based on improved reaction kinetics of POC degradation in model calculations and a new compilation of global input data (see Figs. EA-1-EA-7).

The new estimate of Holocene sedimentation rates presented in this contribution clearly shows that widespread gas hydrate formation is very unlikely to occur under Holocene boundary conditions. Holocene sedimentation is concentrated in shelf environments and is not high enough at continental slopes to form significant hydrates deposits. It appears likely that active upward transport of free methane gas and methane rich pore fluids from underlying sediment sequences is the main driving force for hydrate formation during the Holocene.

The high sedimentation scenario is likely to represent the present, steady-state hydrate budget formed in-situ by organic matter degradation. It assumes that hydrate formation occurs over the entire GHSZ, which includes sediments deposited not only during the Holocene but rather over a time span of several million years. Relatively high rates of sedimentation during the glacial periods of the Quaternary provided gas hydrate formation within continental margins thereby increasing the global budget of hydrates.

In-situ gas hydrate formation is directly limited by the amount of organic matter deposited at the sediment surface. Our studies show that not only the surface concentration of TOC controls hydrate formation but rather the supply rate. Analysis of all individual model runs has further shown that the thickness of the stability zone correlates only weakly with the amount of hydrate formed. 
The present study illustrates how numerical modeling can help to synthesize and assimilate multiple data sets in order to make predictions on the global abundance of marine gas hydrates. Future work should aim at reducing the large span of such global hydrate estimates. For this it will be necessary to improve predictions on physical conditions at the seafloor, obtain converging estimates on methane solubility in seawater, and improve numerical reaction-transport models.

It should be noted that the hydrate accumulations presented in this study do not include hydrate deposits formed by the focused ascent of gas and fluids from deeper sedimentary strata. It is presently not possible to estimate the global amount of these additional hydrate deposits. Regional geophysical surveys and drilling information is needed to better constrain the abundance of these economically promising deposits.

\section{ACKNOWLEDGMENTS}

This paper has benefited from constructive reviews by Alexei Milkov and an anonymous reviewer. We appreciate the helpful comments of Associate Editor David Burdige which helped to improve the manuscript. We thank Arne Biastoch for providing the global bathymetry, bottom water temperature, and salinity data sets and Matthias Haeckel for discussions and helping us setting up the model.

\section{APPENDIX A. SUPPLEMENTARY DATA}

Supplementary data associated with this article can be found, in the online version, at doi:10.1016/j.gca.2011. 05.029 .

\section{REFERENCES}

Archer D. (1996) A data-driven model of the global calcite lysocline. Global Biogeochem. Cycles 10, 511-526.

Archer D. and Buffett B. A. (2005) Time-depended response of the global ocean clathrate reservoir to climatic and anthropogenic forcing. Geochem. Geophys. Geosyst. 6, ISSN 1525-2027.

Archer D., Morford J. L. and Emerson S. R. (2002) A model of suboxic sedimentary diagenesis suitable for automatic tuning and gridded global domains. Global Biogeochem. Cycles 16, ISSN 0886-6236.

Archer D., Buffett B. and Brovkin V. (2008) Ocean methane hydrates as a slow tipping point in the global carbon cycle. Proc. Natl. Acad. Sci. USA 106, 20596-20601.

Athy L. F. (1930) Density, porosity, and compaction of sedimentary rocks. AAPG Bull. 14, 1-24.

Barnier B. (2006) Impact of partial steps and momentum advection schemes in a global ocean circulation model at eddy-permitting resolution. Ocean Dyn. 56, 543-567.

Baturin G. N. (2007) Issue of the relationship between primary productivity of organic carbon in ocean and phosphate accumulation (Holocene - Late Jurassic). Lithol. Min. Resour. 42, 318-348.

Betts J. N. and Holland H. D. (1991) The oxygen content of ocean bottom waters, the burial efficiency of organic carbon, and the regulation of atmospheric oxygen. Palaeogeogr. Palaeoclimatol. Palaeoecol. 97, 5-18.
Boudreau B. P. (1996) The diffusive tortuosity of fine-grained unlithified sediments. Geochim. Cosmochim. Acta 60, 31393142.

Boudreau B. P. (1997) Diagenetic Models and their Implementation: Modelling Transport and Reactions in Aquatic Sediments. Springer-Verlag, Berlin, New York.

Buffett B. and Archer D. (2004) Global inventory of methane clathrate: sensitivity to changes in the deep ocean. Earth Planet. Sci. Lett. 227, 185-199.

Colman A. S. and Holland H. D. (2000) The global diagenetic flux of phosphorus from marine sediments to the oceans: redox sensitivity and the control of atmospheric oxygen levels. In Marine Authigenesis: From Global to Microbial. Society of Sedimentary Geology.

Davie M. K. and Buffett B. A. (2001) A numerical model for the formation of gas hydrate below the seafloor. Rock the Foundation Convention, June 18-22. Canadian Society of Petroleum Geologists.

Davie M. K. and Buffett B. A. (2003) A steady-state model for marine hydrate formation: constraints on methane supply from pore water sulfate profiles. J. Geophys. Res. 108, ISSN 01480227.

Deming D. and Chapman D. S. (1989) Thermal histories and hydrocarbon generation - an example from Utah-Wyoming Thrust Belt. AAPG Bull. 73, 1455-1471.

Dickens G. R., Oneil J. R., Rea D. K. and Owen R. M. (1995) Dissociation of oceanic methane hydrate as a cause of the carbon-isotope excursion at the end of the Paleocene. Paleoceanography 10, 965-971.

Divins D. L. (2003) Total Sediment Thickness of the World's Oceans \& Marginal Seas. NOAA National Geophysical Data Center (NGDC).

Duan Z., Moller N. and Weare J. H. (1992) An equation of state for the $\mathrm{CH}_{4}-\mathrm{CO}_{2}-\mathrm{H}_{2} \mathrm{O}$ system: I. Pure systems from 0 to $1000{ }^{\circ} \mathrm{C}$ and 0 to 8000 bar. Geochim. Cosmochim. Acta 56, 2605-2617.

Garg S. K., Pritchett J. W., Katoh A., Baba K. and Fujii T. (2008) A mathematical model for the formation and dissociation of methane hydrates in the marine environment. J. Geophys. Res. 113, ISSN 0148-0227.

Hamza V. M., Cardoso R. R. and Ponte Neto C. F. (2008) Spherical harmonic analysis of earth's conductive heat flow. Int. J. Earth Sci. (Geol Rundsch) 97, 205-226.

Hantschel T. and Kauerauf A. I. (2010) Fundamentals of Basin and Petroleum Systems Modeling. Springer-Verlag, Berlin, Heidelberg.

Hay W. W. (1994) Pleistocene-Holocene fluxes are not the Earth's norm. In Material Fluxes on the Surface of the Earth (eds. W. W. Hay and T. Usselman). National Academy Press, Washington.

Hay W. W. and Southam J. R. (1977) Modulation of marine sedimentation by the continental shelves. In The Fate of Fossil Fuel $\mathrm{CO}_{2}$ in the Oceans (eds. A. Malahoff and N. R. Andersen). Plenum Press, New York.

Hensen C. and Wallmann K. (2005) Methane formation at Costa Rica continental margin - constraints for gas hydrate inventories and cross-décollement fluid flow. Earth Planet. Sci. Lett. 236, 41-60.

Hutchison I. (1985) The effects of sedimentation and compaction on oceanic heat flow. Geophys. J. R. Astron. Soc. 82, 439459 .

Jickells T. D., An T. S., Andersen K. K., Baker A. R., Bergametti G., Brooks N., Cao J. J., Boyd P. W., Duce R. A., Hunter K. A., Kawahata H., Kubilay N., LaRoche L., Liss P. S., Mahowald N., Prospero J. M., Ridgwell A. J., Tegen J. and 
Torres () Global iron connections between desert dust, ocean biogeochemistry, and climate. Science 308, 67-71.

Kennett J. P. and Stott L. D. (1991) Abrupt deep-sea warming, palaeoceanographic changes and benthic extinctions at the end of the Paleocene. Nature 353, 225-229.

Klauda J. B. and Sandler S. I. (2005) Global distribution of methane hydrate in ocean sediment. Energy Fuels 19, 459-470.

Kleypas J. A. (1997) Modeled estimates of global reef habitat and carbonate production since the last glacial maximum. Paleoceanography 12, 533-545.

Kvenvolden K. A. (1988) Methane hydrate - a major reservoir of carbon in the shallow geosphere? Chem. Geol. 71, 41-51.

Kvenvolden, K.A. and Lorenson, T.D. (2001) The global occurrence of natural gas hydrate. In: Natural Gas Hydrates: Occurrence, Distribution, and Detection (eds. C.K. Paull and W.P. Dillon). Geophys. Monogr. vol. 124, pp. 3-18.

Laske G. and Masters G. (1997) A Global Digital Map of Sediment Thickness. American Geophysical Union.

Lisitzin A. P. (1996) Oceanic Sedimentation: Lithology and Geochemistry. American Geophysical Union, Washington, DC.

Liu X. and Flemings P. B. (2006) Passing gas through the hydrate stability zone at southern Hydrate Ridge, offshore Oregon. Earth Planet. Sci. Lett. 241, 211-226.

Ludwig W., Amiotte-Suchet P. and Probst J.-L. (1999) Enhanced chemical weathering of rocks during the last glacial maximum: a sink for atmospheric $\mathrm{CO}_{2}$ ? Chem. Geol. 159, 147161.

Luff R. and Wallmann K. (2003) Fluid flow, methane fluxes, carbonate precipitation and biogeochemical turnover in gas hydrate-bearing sediments at Hydrate Ridge, Cascadia Margin: numerical modeling and mass balances. Geochim. Cosmochim. Acta 67, 3403-3421.

Marquardt M., Hensen C., Pinero E., Wallmann K. and Haeckel M. (2010) A transfer function for the prediction of gas hydrate inventories in marine sediments. Biogeosciences 7, 2925-2941.

Menard H. W. and Smith S. M. (1966) Hypsometry of ocean basin provinces. J. Geophys. Res. 71, 4305-4325.

Middelburg J. J. (1989) A simple rate model for organic matter decomposition in marine sediments. Geochim. Cosmochim. Acta 53, 1577-1581.

Milkov A. V. (2004) Global estimates of hydrate-bound gas in marine sediments: how much is really out there? Earth Sci. Rev. 66, 183-197.

Milkov A. V. and Sassen R. (2002) Economic geology of offshore gas hydrate accumulations and provinces. Mar. Petrol. Geol. 19, 1-11.

Peltier W. R. (1994) Ice age paleotopography. Science 265, 195201.

Raiswell R., Tranter M., Benning L. G., Siegert M., De'ath R., Huybrechts P. and Payne T. (2006) Contributions from glacially derived sediment to the global iron (oxyhydr)oxide cycle: implications for iron delivery to the oceans. Geochim. Cosmochim. Acta 70, 2765-2780.

Revelle R. R. (1983) Methane hydrates in continental slope sediments and increasing atmospheric carbon dioxide. In
Changing Climate. Report of the Carbon Dioxide Assessment Committee, National Academic Press, Washington, DC.

Rohling E. J., Fenton M., Jorissen F. J., Bertrand P., Ganssen G. and Caulet J. P. (1998) Magnitudes of sea-level lowstands of the past 500,000 years. Nature 394, 162-165.

Romankevich E. A., Vetrov A. A. and Peresypkin V. I. (2009) Organic matter of the World Ocean. Russ. Geol. Geophys. 50, 299-307.

Sarmiento J. L. and Gruber N. (2006) Ocean Biogeochemical Cycles. Princeton University Press, Princeton.

Schmidt M., Hensen C., Mörz T., Müller C., Grevemeyer I., Wallmann K., Mau S. and Kaul N. (2005) Methane hydrate accumulation in Mound 11 mud volcano, Costa Rica forearc. Mar. Geol. 216, 83-100.

Seiter K., Hensen C., Schroter J. and Zabel M. (2004) Organic carbon content in surface sediments-defining regional provinces. Deep Sea Res. I 51, 2001-2026.

Shakhova N. and Semiletov I. (2007) Methane release and coastal environment in the East Siberian Arctic shelf. J. Mar. Syst. 66, 227-243.

Syvitski J. P. M., Vörösmarty C. J., Kettner A. J. and Green P. (2005) Impact of humans on the flux of terrestrial sediment to the global coastal ocean. Science 308, 376-380.

Tishchenko P., Hensen C., Wallmann K. and Wong C. S. (2005) Calculation of the stability and solubility of methane hydrate in seawater. Chem. Geol. 219, 37-52.

Torres M. E., Wallmann K., Trehu A. M., Bohrmann G., Borowski W. S. and Tomaru H. (2004) Gas hydrate growth, methane transport, and chloride enrichment at the southern summit of Hydrate Ridge, Cascadia margin off Oregon. Earth Planet. Sci. Lett. 226, 225-241.

USGS World Energy Assessment Team, 2000. US Geological Survey World Petroleum Assessment 2000-Description and Results.

Wallmann K., Aloisi G., Haeckel M., Obzhirov A., Pavlova G. and Tishchenko P. (2006) Kinetics of organic matter degradation, microbial methane generation, and gas hydrate formation in anoxic marine sediments. Geochim. Cosmochim. Acta 70, 39053927.

Westbrook G. K., Thatcher K. E., Rohling E. J., Piotrowski A. M., Pälike H., Osborne A. H., Nisbet E. G., Minshull T. A., Lanoiselle M., James R. H., Hühnerbach V., Green D., Fisher R. E., Crocker A. J., Chabert A., Bolton C., BeszczynskaMöller A., Berndt C. and Aquilina A. (2009) Escape of methane gas from the seabed along the West Spitsbergen continental margin. Geophys. Res. Lett. 36, ISSN 0094-8276.

$\mathrm{Xu}$ W. and Ruppel C. (1999) Predicting the occurence, distribution, and evolution of methane gas hydrate in porous marine sediments. J. Geophys. Res. 104, 5081-5095.

Zatsepina O. Y. and Buffett B. A. (1998) Thermodynamic conditions for the stability of gas hydrate in the seafloor. $J$. Geophys. Res. 103, 24127-24139.

Associate editor: David J. Burdige 